\title{
Thoracoscopic instruments do not interfere in the outcome of uncomplicated, experimental, video-assisted pulmonary lobectomy
}

\section{Instrumentos toracoscópicos não interferem no desfecho da lobectomia pulmonar videoassistida experimental não complicada}

Leonardo Cesar Silva Oliveira ${ }^{1}$ (D); Josue Viana Castro ${ }^{1}$

\author{
A B S T R A C T
}

\begin{abstract}
Objective: Since its first report, video-assisted thoracic surgery (VATS) lung lobectomy was carried out with the use of conventional surgical instruments, used in laparoscopy and open thoracotomy. These instruments are expensive, not standardized and there are a variety of models and manufacturers. The aim of this study was to determine the impact of the use of these instruments on the experimental pulmonary lobectomy. Methods: We used a modified surgical simulator that uses a porcine heart-lung block filled with tomato sauce, and tested specific (Group 1) and regular (Group 2) instruments. Each group includes 15 experiments. Results: The median total time, excluding the time spent to correct the lesions, was 45.08 and 45.81 minutes, respectively in Group 1 and Group 2. There was no statistical difference between the total times $(p=0.58$ ). The only statistically different was seen for partial times regarding the elapsed time to cut and suture of lung fissures ( $p=0.03$ and 0.04 , respectively). There were more direct lesions and indirect leaks in Group 2, but without statistical significance ( $p=1.000$ and $p=0.203$, respectively). The mean time spent for the diagnosis and correction of these events was 1.77 minutes with a standard deviation of 1.18 for Group 1 and $2.72 \pm 1.11$ minutes for Group $2(p=0.044)$. Conclusion: The use of minimally invasive instruments is not associated with time improvement spent with experimental video-assisted lung lobectomy and does not lead to a faster or safer surgery. The use of VATS instruments makes correction of adverse events faster when they occur.
\end{abstract}

Keywords: Thoracic Surgery, Video-Assisted. Surgical Instruments. Performance Tests.

\section{INTRODUCTION}

$\mathrm{P}$ ulmonary lobectomy by video-assisted thoracic surgery (VATS) continues to grow as a form of preference for pulmonary resection ${ }^{1}$. Since the first reports of VATS lobectomy, incisions have reduced in number and size. The pioneering authors reported that only laparoscopic and thoracotomy instruments were sufficient to complete these surgeries ${ }^{2-4}$. In recent years, some new and specialized instruments have been launched and promise to guarantee better results and offer better ergonomics. Many of these instruments were designed or suggested by surgeons and have become every surgeon's dream, although some of them have never become commercial ${ }^{5-7}$. Most of the new instruments were introduced by companies such as Scanlan International (St. Paul, MN, USA), Pilling Surgical (Horsham, PA, USA), Thoramet (Rotherford, NJ, USA) among others. A consensus in the literature is the benefit of using the soft tissue retractor ${ }^{8-9}$. Studies on the impact of how specific instruments interfere in the conduct and success of a surgical procedure are scarce, many of them limited to presenting innovation ${ }^{10-18}$. Some instruments were designed for specific approaches, such as mono-portal, subxiphoid or transcervical VATS lobectomy ${ }^{15,19,20}$. All of these instruments have limited dissemination, mainly in developing countries, due to their high cost. The apparently logical statement that the use of VATS instruments makes pulmonary lobectomy faster and safer is the objective of this research that compares experimental lobectomy with the two types of instruments (VATS-dedicated versus regular open surgery).

\section{METHODS}

We performed 30 experimental VATS lobectomies. We designed the experiment so as to 
control the variables and record the consequences of using or not using thoracoscopic instruments in VATS lobectomy, using a known and validated simulator with some improvements ${ }^{21-24}$. The simulator used has realistic organic tissue: a pig heart-lung block with filling of vascular structures with tomato sauce (ketchup). We excluded blocks in which it was not possible to fill the vascular structures adequately or where anatomical variations of the vessels or the respiratory tree of the left lung were detected during the experiment. The improvement made was the use of a polyvinyl mannequin to simulate the rib cage (Figure 1). For the incision, we prepared the mannequin to simulate a two-port VATS lobectomy approach, as already published by Burfeind \& Amico ${ }^{25}$. We used a conventional VATS imaging system (Karl Storz, Tutlingen, Germany) with a static arm for optics (Estech, San Ramon, CA, USA).

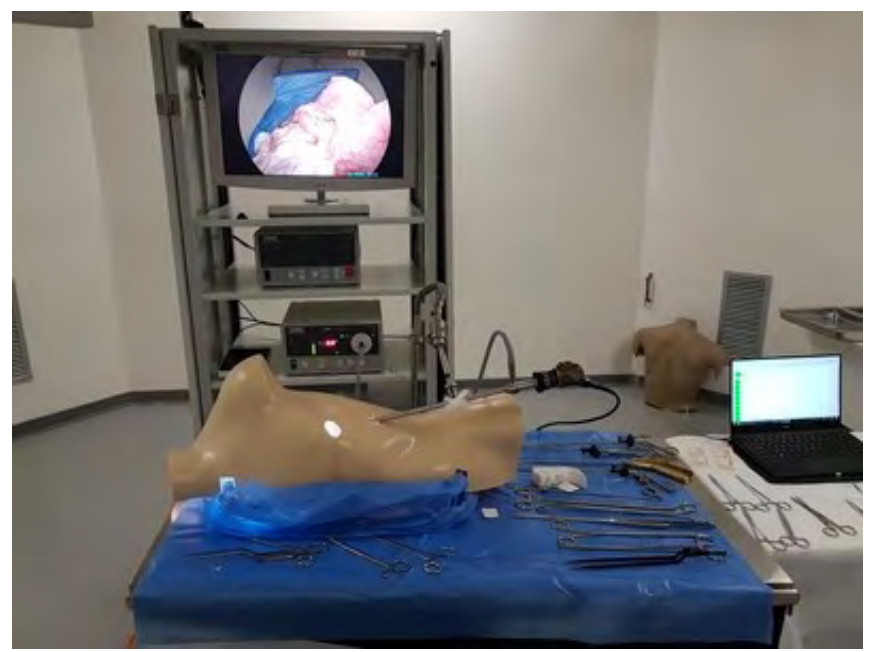

Figure 1. Simulator assembled for use.

Pulmonary lobectomy by VATS comprised into 11 steps (Table 1).

Table 1. Variables and steps for experimental upper left pulmonary lobectomy.

\begin{tabular}{cl}
\hline Variable & \multicolumn{1}{c}{ Step description } \\
\hline T1a & $\begin{array}{l}\text { Dissect and isolate the left upper } \\
\text { pulmonary vein }\end{array}$ \\
T1b & $\begin{array}{l}\text { Suture and divide the upper left } \\
\text { pulmonary vein and cut the threads }\end{array}$ \\
T2a & $\begin{array}{l}\text { Dissect and isolate the first branch of the } \\
\text { pulmonary artery to the left upper lobe }\end{array}$ \\
T2b & $\begin{array}{l}\text { Suture and divide the first arterial branch } \\
\text { and cut the threads }\end{array}$ \\
\hline
\end{tabular}

T3a

Dissect, isolate and divide the upper left bronchial stump

T3b Suture the upper left bronchial stump with 2 double stitches

T4a Dissect and isolate the second arterial branch to the left upper lobe

$\mathrm{T} 4 \mathrm{~b}$ Suture and divide the second arterial branch and cut the threads

T5a Clamp and divide the oblique fissure

$\mathrm{T} 5 \mathrm{~b}$ Suture the oblique fissure and cut the thread

T6 Remove the upper lobe from inside the mannequin through the working incision

Total time Sum of all steps except the time to correct injuries

We recorded the time to perform and complete the VATS lobectomy using a computer system created to record the beginning and end of each step, as well as the occurrence of injuries directly induced by the operator and indirect leaks. A second observer recorded these times in the computer system. Direct injury was the occurrence of sauce leakage in the structure being dissected in that step and caused directly by the action of one of the instruments. Indirect leakage was the escape of sauce in a different structure than the one being dissected. We also recorded the time taken to correct injuries or leaks as a separate variable. The total time of the experiment was the sum of each time of the VATS lobectomy steps minus the time lost to correct injuries and leaks. This was necessary to ensure that all experiments were comparable. We analyzed the time to correct injuries and leaks as a separate variable.

We performed the experiments always in pairs, one per day, using dedicated instruments for VATS lobectomy (Group 1 - Figure 2) or with regular surgical equipment (Group 2 - Figure 3). In Group 1, we used instruments that included tweezers manufactured by Scanlan International (St. Paul, MN, USA), Techmed (Recife, PE, Brazil) and Storz (Karl Storz, Tuttlingen, Germany), all with double articulation and coaxial body. Group 2 included only regular thoracotomy instruments. In Group 1, we used a Karl Storz knot positioner (Model 26596 T), while in Group 2 we tightened the knot using the classic mixer clamp technique ${ }^{16}$. We performed only one experiment per day to exclude operator fatigue as a variable. To standardize both groups, the number of sutures, knots and 
the order of the dissected hilar structures were the same between groups. The only difference between the groups were the instruments used. The suture technique was with double transfixing stitches and manual tying. We selected polyester suture to ensure a good suture sliding in both groups. The first author, an experienced thoracic surgeon with more than 100 VATS and thoracotomy lobectomies and with 12 years of practice, carried out all experiments. We recorded all experiments on video for future analysis. We analyzed the collected data using the IBM SPSS statistics for Windows version 23.0 (IBM Corporation, Armonk, NY, USA) using median and interquartile range (IQR) or mean and standard deviation. We considered a $p$ value less than 0.05 as significant.

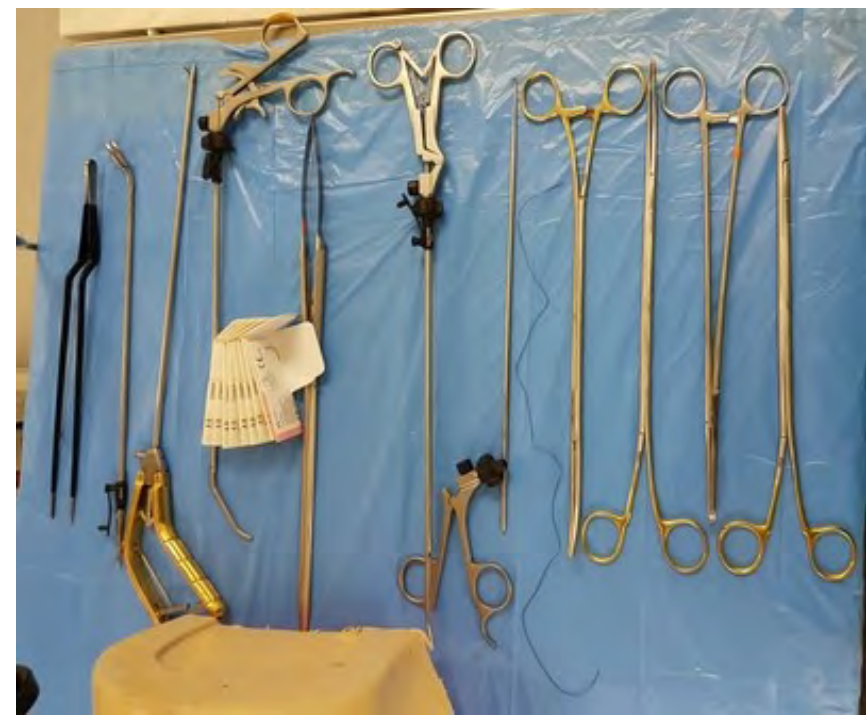

Figure 2. Group 1 - Specialized instruments for video-assisted thoracic surgery.

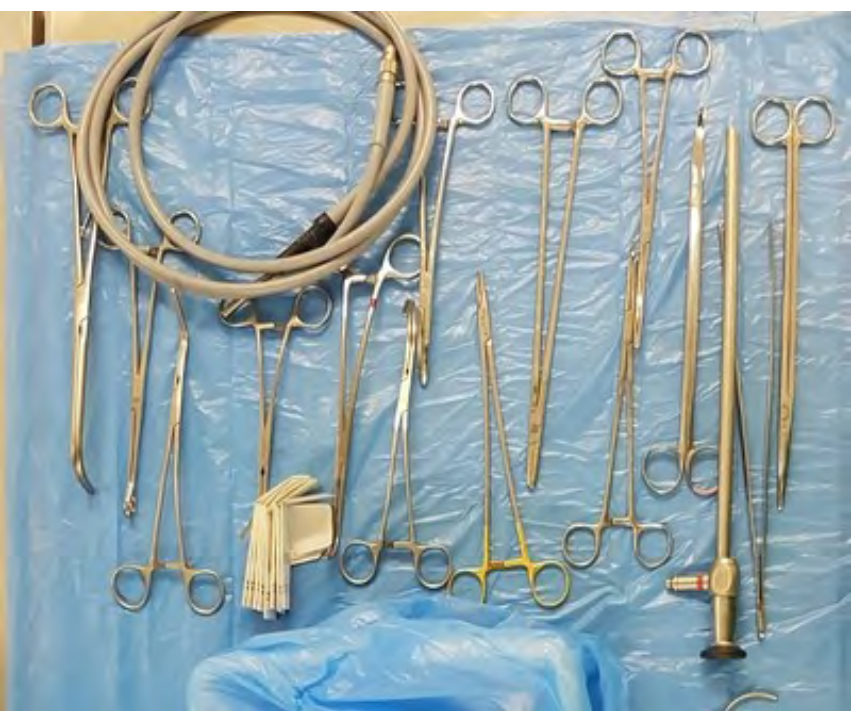

Figure 3. Group 2 - Classical/conventional instruments.

\section{RESULTS}

The median total time required for VATS lobectomy was 45.08 (IQR 40.90 51.98) and 45.81 (IQR 42.02 55.15) minutes for Group 1 and Group 2, respectively $(p=0.58)$. Two variables were different between groups: the time needed to clamp and divide the fissure (T5a) and the time to suture it (T5b) with a mattress suture followed by a continuous suture $(p=0.03$ and 0.04 , respectively) (Table 2 ).

Table 2. Time required for each of the 11 steps - Median and interquartile range.

Group $1(n=15) \quad$ Group $2(n=15) \quad p$-value ${ }^{a}$ Variable Median (IQR) Median (IQR)

T1a $3.75(3.30-4.70) \quad 3.57(2.47-5.25) \quad 0.35$

T1b $6.00(5.10-6.73) 6.65(5.53-7.85) \quad 0.60$

T2a $3.91(3.18-5.07) \quad 3.40(2.85-4.28) \quad 0.25$

T2b $6.55(5.52-8.17) 7.07(6.70-9.42) \quad 0.17$

T3a $5.35(4.90-6.90) 4.70(3.18-6.03) \quad 0.44$

T3b $3.33(1.83-5.30) \quad 4.48(1.80-5.88) \quad 0.27$

T4a $2.27(1.17-3.10) \quad 2.22(1.65-3.58) \quad 0.48$

T4b $6.77(5.68-8.35) \quad 6.30(5.15-8.02) \quad 0.36$

T5a $1.80(1.43-2.18) 2.63(1.80-2.87) \quad 0.03$

T5b $3.12(3.00-3.50) 3.77(3.05-4.10) \quad 0.04$

T6 $0.33(0.27-0.43) \quad 0.37(0.23-0.68) \quad 0.71$ $\begin{array}{cccc}\text { Sum of } & 45.08(40.90- & 45.81(42.02- & 0.58 \\ \text { times } & 51.98) & 55.15) & \end{array}$ a: Mann-Whitney test; IQR - interquartile range; Group 1 - Dedicated instruments; Group 2 - classical/conventional instruments.

The time to correct the 27 adverse events during the steps of the 30 lobectomies had a mean and standard deviation of $1.77 \pm 1.18$ and $2.72 \pm 1.11$ minutes in Group 1 and Group 2, respectively ( $p=0.044)$. There was only one direct vascular lesion in Group 1 caused by the scissors in the left upper pulmonary vein, and two in Group 2, both in the pulmonary artery (Table 2). The analysis of the 11-step variables showed a significant difference in time $(X 2(10)=220.728$; $p<$ $0.001)$ 


\section{DISCUSSION}

It seems logical to say that the use of dedicated and specialized instruments for VATS lobectomy would probably offer a better result. The dedicated instruments for VATS are thinner and of the correct length, made with tips specially designed to guide the dissection with the promise of better ergonomics. The double articulation and the coaxial body promise better ergonomics and less confrontation between the instruments inserted together in a narrow intercostal space. For VATS lobectomy, the pistol grip, commonly used in laparoscopic surgery, is inadequate, offering less precision and more crossings with other instruments inserted through VATS working incision. The opposite happens with the coaxial grip, similar to conventional instruments, which offers a faster adaptation to surgeons trained in traditional open thoracotomy. In addition, the pencil-type handle determines greater precision and less crossings ${ }^{15}$.

The time for VATS lobectomy using this simulator was equivalent to that recorded in the study that validated the simulator used. The time of 45 minutes was compared to that of 37 minutes for experienced surgeons. The difference is probably justified by the fact that in the simulator validation, mechanical suture was used in the vascular structures, bronchus and lung parenchyma. In the present study, we ligated all structures with endosutures ${ }^{22}$

The shorter time to clamp, divide and suture the fissure with specialized VATS instruments (Group 1) may be justified by the need to hold the lung parenchyma in a deep field. In this step, the use of VATS instruments can facilitate surgical maneuvers. Direct vascular injuries were equivalent between groups as well (one in Group 1 and two in Group 2). We must note that the porcine lung has no hilar lymph nodes, so the vascular structures are separated only by a small amount of connective tissue and fat. In humans, these lymph nodes serve as an anatomical landmark and protect the dissection of the thin-walled pulmonary vein and the very fragile pulmonary artery.

The time to correct injuries and leaks was shorter with the use of specialized VATS instruments. In this situation, the use of these instruments seems to be the best choice, despite the small sample. However, the methodological design removes the anatomical variability commonly found in daily practice. Perhaps in the face of anatomical unpredictability, the use of VATS instruments can further increase this difference, in addition to maybe changing the non-significant findings. The lack of studies that measure the time needed to correct injuries in a comparative way prevents further analysis of the results. A previous review suggested that the best visualization of systems in three dimensions and the superiority of robot lobectomy instruments allow a lymphadenectomy equivalent to that performed in open lobectomy or by VATS $^{26}$. The research by Tong et al used the occurrence of injuries only as a penalty indicator, adding 3 minutes to validate the construction of the used simulator ${ }^{22}$.

Every surgeon has his or her preferences and is usually sure that his/her technique and approach is the best. The impression watching the videos of the experiments is that, regardless of the instrument used, in experienced hands, the movements to dissect and suture the pulmonary hilar structures are the same and require very similar time. If five or six actions of the instrument are required to surround a pulmonary vessel, it does not matter which instrument it is. Comfort and ergonomics are difficult aspects to register with the method used. Surgeons commonly like to experiment with new instruments. The significant difference between the steps' times probably shows a different difficulty to perform them.

An important point in VATS lobectomy is the size of the working incision, although this aspect has not been objectively studied before. Through this incision, multiple instruments are inserted at the same time and smaller incisions can be a real limitation to regular thoracotomy instruments. In this series, we used the same mannequin in both groups, standardizing the incision. In daily practice, the width of the patient's intercostal space can cause greater difficulty in conventional instruments, and the use of specialized VATS instruments can interfere with the ease of performing the surgical maneuvers necessary for VATS lobectomy.

\section{CONCLUSION}

Despite the limitations, as this is an experimental study, the results show that there is no superiority of the 
VATS instruments for an uneventful pulmonary lobectomy.

Thus, it is likely that in clinical practice and in complex cases, the VATS instruments may offer advantages, requiring further studies in this regard.

\title{
R E S U M O
}

\begin{abstract}
Objetivo: desde os primeiros registros, a lobectomia pulmonar por cirurgia torácica videoassistida (CTVA) foi feita usando instrumentos convencionais e de laparoscopia. Recentemente instrumentais específicos para CTVA surgiram. Esses instrumentais têm custo elevado, não são padronizados existindo uma variedade de modelos e fabricantes. Buscou-se determinar o impacto do uso desses instrumentais na realização da lobectomia pulmonar superior esquerda experimental. Métodos: foi usado simulador modificado com bloco de coraçãopulmões preenchidos com molho de tomate para testar o uso de instrumental dedicado de CTVA e de cirurgia convencional (Grupo 1 e Grupo 2, respectivamente). Cada grupo inclui 15 experimentos. Resultados: a mediana do tempo total, excluído o tempo para corrigir vazamentos, foi de 45, 8 e 45,81 minutos, respectivamente para o Grupo 1 e Grupo 2. Não houve diferença estatisticamente significante entre os tempos totais $(p=0,58)$. Os únicos tempos parciais estatisticamente diferentes foram os para cortar e suturar a fissura pulmonar ( $p=0,03$ e 0,04, respectivamente). Ocorreram mais lesões diretas e vazamentos indiretos no Grupo 2, mas sem significância estatística ( $p=1,000$ e 0,203, respectivamente). A média de tempo gasto para diagnosticar e corrigir os eventos de lesão e vazamento foi de 1,77 minutos com desvio padrão de 1,18 para o Grupo 1 e 2,72 1,11 minutos para o Grupo 2 ( $p=0,044)$. Conclusão: o uso de instrumentos para CTVA não torna a cirurgia mais rápida, nem mais segura. O uso de instrumentos de CTVA permitiu uma correção mais rápida dos eventos adversos ocorridos.
\end{abstract}

Palavras chave: Cirurgia Torácica Videoassistida. Instrumentos Cirúrgicos. Eficiência.

\section{REFERENCES}

1. Detterbeck F, Molins L. Video-assisted thoracic surgery and open chest surgery in lung cancer treatment: present and future. J Vis Surg. 2016;2:173.

2. Roviaro G, Rebuffat C, Varoli F, Vergani C, Mariani C, Maciocco M. Videoendoscopic pulmonary lobectomy for cancer. Surg Laparosc Endosc. 1992;2(3):244-7.

3. Kirby TJ, Mack MJ, Landreneau RJ, Rice TW. Initial experience with video-assisted thoracoscopic lobectomy. Ann Thorac Surg. 1993;56(6):1248-52; discussion 1252-3.

4. Lewis RJ, Caccavale RJ, Sisler GE, Mackenzie JW. One hundred consecutive patients undergoing video-assisted thoracic operations. Ann Thorac Surg. 1992;54(3):421-6.

5. Sato, Tezuka Y, Kanai Y, Otani S, Yamamoto S, Tetsuka $K$, et al. Novel retractor for lymph node dissection by video-assisted thoracic surgery. Ann Thorac Surg. 2008;86(3):1036-7

6. Tanaka R, Nakazato Y, Goya T. The development of new instruments (NT forceps) for video-assisted thoracoscopic surgery. Surg Today. 2011;41(2):3035.

7. Zhao, Jiang G, Chen C, Dai C, Zhu Y. Easier Uniportal VATS Lobectomy Using a Clamp With a String and a U-shaped Direction Converter for Lung Traction. Ann Thorac Surg. 2016;102(3):e265-e7.
8. Tsunezuka $\mathrm{Y}$, Oda M, Moriyama H. Wound retraction system for lung resection by videoassisted mini-thoracotomy. Eur J Cardiothorac Surg. 2006;29(1):110-1.

9. Raveglia F, Cioffi U, De Simone M, Rizzi A, Leporati A, Tinelli $C$, et al. Advantages of wound retractor device versus rigid trocar at camera port in video-assisted thoracic surgery-a single institution experience. J Vis Surg. 2018;4:66.

10. Yim AP, Lee TW. 'Homemade' knot pusher for extracorporeal ties. Aust N Z J Surg. 1995;65(7):5101.

11. Naruke T, editor. Original instruments for videoassisted thoracoscopy surgery. Proceedings of the 13th World Congress for Bronchology; 2004 Jun 2023; Barcelona, Spain.

12. Rocco G. A new instrument for intraoperative visualization of safe surgical margins for small lung nodules. Semin Thorac Cardiovasc Surg. 2018;30(1):92-4.

13. Demmy TL, Mayfield WR. Anvil extension technology in thoracic surgery. Ann Thorac Surg. 2012;93(4):1280-4.

14. Wei $B$, Jiang $F$, Yin J. A specific instrument to facilitate thoracoscopic ligation. Thorac Cardiovasc Surg. 2014;62(6):525-7.

15. Özyurtkan MO, Kaba E, Toker A. Technological innovation in video-assisted thoracic surgery. J Vis Surg. 2017;3:20. 
16. Bo W, Fusheng J, Tianyou W. A novel ligation technique facilitating minithoracotomy. Ann Thorac Surg. 2009;88(6):1989-92.

17. Muranishi $Y$, Sato $T$, Ueda $Y$, Yutaka $Y$, Nakamura T, Date $H$. A novel suction-based lung-stabilizing device in single-port video-assisted thoracoscopic surgical procedures. Gen Thorac Cardiovasc Surg. Epub 2019 Nov 19. doi: 10.1007/s11748-01901249-6.

18. Ji Y, Qiu B, Gao S. The powered vascular staple (PVS) versus conventional powered linier cutter (PLC) for the application of bronchial transection in thoracoscopic anatomic segmentectomy. J Thorac Dis. 2019;11(11):4647-53.

19. Zhu Q, Xiao H, Xu E, Liao M, Tang Y, Xuan Y, et al. From open to single port video-assisted thoracoscopic lobectomy: a stepwise and return progression of the experience from Department of Thoracic Surgery, General Hospital of Guangzhou Military Command of P.L.A. J Thorac Dis. 2015;7(7):1252-63.

20. Hernandez-Arenas LA, Guido W, Jiang L. Learning curve and subxiphoid lung resections most common technical issues. J Vis Surg. 2016;2:117.

Received in: 09/12/2019

Accepted for publication: 26/03/2020

Conflict of interests: no.

Funding source: none.
21. Meyerson SL, LoCascio F, Balderson SS, D'Amico TA. An inexpensive, reproducible tissue simulator for teaching thoracoscopic lobectomy. Ann Thorac Surg. 2010;89(2):594-7.

22. Tong BC, Gustafson MR, Balderson SS, D'Amico TA, Meyerson SL. Validation of a thoracoscopic lobectomy simulator. Eur J Cardiothorac Surg. 2012;42(2):364-9.

23. Avila R, Achurra P, Tejos R, Varas J, Solovera M, Salas $P$. Uniportal video-assisted thoracic surgery lobectomy using a novel perfused ex vivo simulation model. J Vis Surg. 2016;2(155):1-3.

24. Meyerson SL, Balderson SS, D'Amico TA. Training assistants improves the process of adoption of video-assisted thoracic surgery lobectomy. Ann Thorac Surg. 2015;100(2):401-6.

25. Burfeind WR, Amico TAD. Thoracoscopic lobectomy. Oper Tech Thorac Cardiovasc Surg. 2004;9(2):98114.

26. Toker A, Öguzhan MO, Kaba E. Nodal upstaging: effects of instrumentation and three-dimensional view in clinical stage I lung cancer. J Vis Surg. 2017;3:76.

\section{Mailing address:}

Leonardo Cesar Silva Oliveira

E-mail: leonardo@toracica.med.br

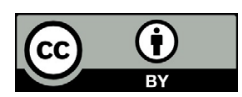

